\title{
Impact of Carroll CSR's Pyramid on Firm's Financial Performance in Pakistan as a Developing Country
}

\author{
MAQSOOD HAYAT \\ Yunnan University of Finance and Economics, Kunming, China. \\ Email: drhayat2019@gmail.com
}

SHEHZAD KHAN

Institute of Business Studies and Leadership, Abdul Wali Khan University Mardan.

ASIF IQBAL

Department of Management Sciences, Alhamd Islamic University, Islamabad.

\begin{abstract}
The aim of this study is to examine the impact Carroll CSR's Pyramid on the firm's financial performance of the top companies listed on Pakistan's stock exchange. The financial performance is proxied by earning per share (EPS), however, the Carroll CSR's Pyramid is undertaken as; economic, philanthropical, legal and ethical environment of the firm. Panel data analysis of top 25 firms listed on Pakistan Stock Exchange during 2011 to 2015 is carried to determine the impact of Carroll CSR Pyramid on firm financial performance. The study found that the economic and philanthropic dimensions are statistically significant impact on the firm's financial performance. However, the legal and ethical dimensions were found statistically significant only with the help of a fixed-effects model. This study concluded that engagement in CSR activities is valuable; however, it is also not necessary that every dimension of the CSR generate the same corporate benefits in developing countries. The sequences of the layers of CSR pyramid were also revisited to attest the notion that the concept of CSR differs geographically from place to place and even time to time.
\end{abstract}

Keywords: CSR, Carroll CSR's Pyramid, Ethical, Philanthropical.

\section{Introduction}

CSR is the social commitment of the business community to align their relationship with the stakeholders based on trust, transparency and mutual respect. CSR is considered to be one of the best corporate strategy to minimize the corporate negativity, enhance the legitimacy and stabilize the relationship with all stakeholders. Due to its dual nature effects, the subject of CSR is considered to be one of the highly interesting topics among corporate practitioners and academic researchers. The firms which are not involved in CSR activities are exposed to legal, social and economic enquiries from the stakeholders. Carroll (1991) introduced four dynamics of CSR in hierarchal order (i.e. economic, legal, ethical, philanthropic), which is called the CSR pyramid. Later on, Elkington (1997) introduced the concept of the triple bottom Line (TBL) by integrating three dynamics of CSR outputs, which is called the 3Ps model. The theory of 3Ps favours that a corporation should have the duties to be profitable for the owners and investors while socially responsible for a human being and sensitive to the environment.

Western countries have more contribution to CSR literature, both theoretically and empirically and were practically implemented not only by profitable organizations but also by non-profitable organizations in the developed world (Fox, 2004). Since the last decades of the 20th century, business community had adopted and implemented a wider range of CSR indicators, ranging from modest environmental defence fund 
(1990) to worldwide acceptable reporting initiative launched by Global Reporting Initiative (GRI) in 2011, which has a positive impact on a vast cluster of stakeholders. The enterprises are well aware of this concept and possess the strength to streamline their corporate strategy and specify the corporate activities which are parallel to the local needs. Like other developing countries, CSR activities in Pakistan revolve around the health, education, and social development projects (Khan, Majid et al. 2013). Sheikh and Beise-Zee (2011) emphasized that the business community should first identify the local issues of the community and then align corporate resources to improve the concerning problems and properly communicate with the stakeholders. CSR activities are magical tools to propagate corporate positive image, which ultimately enhance reputation, mutual trust and the everlasting relationship between the organization and outer community if understood and implemented properly. The expectations of the stakeholders are scattered and multidimensional in developing countries or failed states, therefore the enterprises may face more obstacles and challenges in such region where institutions are weak, politically unstable and uncertainty is high (George et al, 2016). In Pakistan, CSR policies and strategies are implemented by a number of the International organization. However, there are still low trends in the domestic and small enterprises operating in developing countries. This study will speculate to rearrange the sequences of CSR dimensions according to the context of Pakistan. The aim of this study is to explore the truth about the local CSR pyramid specific to the local needs of the society, which is not only a cost or burden on the firm resources but also produce output in shape of firm performance (FP hereinafter).

1. What is the sequence of the Carroll's CSR pyramid in Pakistan as a developing country?

2. Are all of the CSR's dimensions equally important for the firm performance?

\section{Literature Review and Hypotheses Development}

According to Fredrick (1960), the business communities should have the responsibility of enhancing the social and economic value simultaneously. The author defines that CSR is the willingness of the corporation to utilize corporate resources for the betterment of the society, not only for generating profit and firm value. Walton (1967) defined it in ethical perspective that it is the discretion of the firm to behave responsibly, while Davis (1973) stated that it is the corporation's concern and reaction to a problem beyond solely financial, technological and legal liabilities (Davis, 1973, p. 312). Carroll (1979, 1983 and 1991) introduced the famous CSR model which is called Carroll CSR's pyramid. Clarkson (1995) introduced an outline to define the corporate objectives by stating that "the survival and continuing profitability of the corporation depends upon its ability to fulfill its economic and social purpose, which is to create and distribute wealth or value sufficient to ensure that each primary stakeholder group continues as part of the corporation's stakeholder system" (p. 110). CSR can build strong tie with the stakeholders, still there are many intermediaries and variables involved (Lindgreen and Swaen, 2010). According to some scholars, this is not necessary that CSR "investment" always creates a positive relationship between corporation and stakeholders or enhance the firm's performance. Due to the complex scenario, CSR does not necessarily enhance the positivity among stakeholder in all the cases and such in the case of the economic output of the firm (Husted, 2003).

It was already discussed that all of the CSR theories were framed in developed countries context. However, these types of theories are under objections in the context of developing countries (Frynas, 2005). By taking the example of CSR pyramid, the hierarchal distributions of the pyramid's layers are according to their importance and urgencies. The first layer is about the economic profit for the corporation, which means to generate profit for the owner and shareholders. The second step is the obeying of rules and regulations of the country while the third layer is for embracing the norms and values of the society and local culture. The last layer is about the voluntary donation, which means the intentions to give back the portion of the corporate profit to the vulnerable people of the society. CSR dimension that is prioritized in western countries may not be necessary to be beneficial to the same extent in developing countries. Carroll stated that the economic gain is the sole reason of a corporate existence and continuous operation. In more simple words, the corporation should have the right to make an economic gain, fulfill the rules and 
regulations of the land, obey the ethical standards of the society and behave like a good citizen. These four steps have been prioritized according to its performance and urgency. The 2nd step cannot achieve without the attaining of the first step and thus the 3rd and 4th one in sequence. Basically, this pyramid supports the shareholder's theory and stakeholder's theory at the same time. Carroll defends the shareholder's theory by stating that if a corporation wants to be more beneficial for the society and overall stakeholders, it must be a profitable. Similarly, stakeholders can only expect and demand from a profitable corporation. Propagating the stakeholder's theory, the author claimed that profit-generating is not the only aim of the corporation if there is a violation of the law and social norms.

Many researchers (e.g. Podnar \& Golob, 2007; Maignan, 2001) used this pyramid in their CSR studies to testify the urgency of profit generation, act lawfully, obey general acceptable norms and values of the society and behave like a good citizen. According to Windsor (2001), the economic and legal dimensions of CSR pyramid are societal requirements and are mandatory in nature, while philanthropy dimension is not a basic requirement but socially expected. The order of CSR pyramid's layers was criticized by many authors (e.g. Matten et al, 2005; Visser, 2006) by arguing that it is only applicable in developed and western countries. Burton et al (2000) investigated the student's cluster and found that the priorities of CSR dimensions are varying from Hong Kong and the United States. Chapple and Moon (2005) found that the elements of CSR varying from country to country while conducting their CSR study in seven Asian countries. These findings in global context confirm that the classification of CSR dimensions is advocating by Carroll, but their significance varies from country to country. Crane and Matten (2004) investigated the drawback in CSR model by stating that it "does not sufficiently discourse the issue of what should happen when two or more responsibilities are in conflict". Visser (2006), wrote in his article "Revisiting Carroll's CSR Pyramid, An African perspective" that the order of CSR pyramid should be prioritized by economic, philanthropic, legal, and ethical in a hierarchal manner, from more urgency towards less urgency, according to the local needs and vulnerability of the developing countries. Unfortunately, the stakeholders in developing countries have restricted the wide scope of CSR to philanthropic dimension only. Similarly, the corporations in developing countries are more focusing the philanthropic activities to improve the living standards of the general public for long-term corporate benefits. Gabriel (1972) stated that the CSR dynamics in developing countries are restricted only to philanthropic activity. According to Jamali and Miurshak (2007), the CSR in developing countries (Lebanon) are understood only by philanthropic dimension, there is no other element of CSR.

In such case, the corporation should have the knowledge to identify these elements and prioritize these forces to achieve the corporate objectives and satisfy the stakeholders' demands simultaneously. It is very important for a corporation to bear in mind the necessities and authenticities of the operating societies and culture before strategizing or engaging in CSR activities. Unfortunately, most of the studies in the field of CSR and particularly the investigation of CSR pyramid were conducted in developed countries context only. This study is an attempt to investigate the order of different elements of Carroll CSR in developing countries. In the light of this discussion, it is hypothesized that:

H1a. The sequence of CSR's pyramid layers is not similar in developing countries.

H1b. The urgency of philanthropic dimension is more important than all other layers of CSR's pyramid in developing countries.

In addition to disclose the actual corporate information, corporate managers are liable to protect the stakes of all beneficiaries, safeguard and multiply the principal amount of the investors. Ullmann (1985) negates the above argument by stating that an enterprise having "poor" CSR record (or with high CSR expenses) tend to disclose less information. The reason is lying in the rationale that investment in these CSR activities utilized more budget than another project which was much beneficial for shareholders. Therefore, it is very important to highlight the exact relationship between every dimension of CSR with the firm performance. 
Economic Dimension: According to Carroll (1979 \& 1991), the economic dimension is about earning profit, providing attractive employment, and producing quality products. Economic driver is the key purpose for any corporation either in shape of return on the invested amount or enhancing the firm value and sales. This is essential for the corporate existence, until and unless it doesn't disturb the importance of other dimensions of the pyramid. Carroll (1979) anticipated that even this is not an obvious conclusion among financial and other social dynamics; however, all of these dimensions were placed in proper hierarchal order according to their importance for business and over stakeholders. Campbell (2007) criticized the Carroll's CSR pyramid but reinstate the argument regarding the economic dimension of CSR pyramid by stating that economically weak firms will not be willing to participate in CSR activities. According to Crane \& Matten (2004), the economic responsibility is focused only on generating profit for the firm and revenue for the investors in the American context, while this responsibility is widespread in a European context. Ullmann (1985) suggested that an enterprise should attain a satisfactory level of financial position before bestowing corporate resources for social development. This argument is in the favor that an enterprise having already a strong financial position seems to be more willing to involve in CSR activities and thus corporate social responsibility disclosure (CSRD hereafter). From the above discussion it is concluded that the only motive for the corporate existence is the economic motive, so it is hypothesized that:

H2a: There is a positive relationship between the economic dimension and FP.

Philanthropic Dimension: According to Carroll (1979 \& 1991), the philanthropic dimension is describing the contributions of corporate resources in the shape of time and money for societal betterment and prosperity. Mescon and Tilson (1987) observed that an enterprise can get a competitive advantage by incorporating philanthropy and donation. Similarly, Brammer and Millington (2004) while analyzing the corporate giving in form of donations in the years of 1989 and 1990 observed that these types of activities have a definite linkage with the corporate benefits. Porter and Kramer (2003) proposed a context-focused philanthropic methodology for a corporation to satisfy the social needs by corporate resources to promote harmony and mutual benefits. Gardberg and Fombrun (2006) extended the argument of Porter and Kramer (2006), by stating that corporate philanthropy can produce positive corporate value by developing a firm reputation. Jamali et al. (2009) observed that the donation/ charity has religiously (Islam) rooted, and thus enterprise can use it as a useful tool for marketing and public relationship. Pakistan has an immense arrangement for charity/donation and the enterprises are reacting to these strong social/religious forces for corporate legitimacy. For that reason, it seems difficult for enterprises to escape from these local dynamics. From this discussion, it is hypothesized that:

H2b: There is a positive relationship between the philanthropic dimension and FP.

Legal Dimension: According to Carroll (1979 \& 1991), the legal dimension is comprised of submission and obeying the laws and the rules of the game. Practically, corporations operating in developing countries are less sensitive to legal dimension due to lack of freedom, resources and efficiencies to practice institutional power. Similarly, the presence of corrupt government institutions in developing countries creates loopholes for corporations to avoid the rule of the land. The fulfillment and obligations of these formalities are time-consuming and resource diverted, where the legal system is not strong. In this situation, enterprises are more benefited by violating the legal procedure than obeying the law. According to Nidumolu et al (2009), "Enterprises that focus on meeting emerging norms get more time to experiment with materials, technologies and processes". Such type of scenario has equipped the corporate managers to avoid the CSR activities. Moreover, the expansion in internationalization have tightened the regulations and formed a very complex "corporate constitution", which is very difficult for enterprises to obey. There are evidences about the enterprises that are not behaving in responsible and sustainable ways (e.g. Meadows et al, 2004; Unerman \& Chapman, 2014). Governments in developing countries are usually responding with little motivations with weak legal execution, thus building pollution heavens for international investors to attract them towards their countries (Campbell, 2007; Moon and Vogel, 2008). Developing countries are 
considered to have unique characteristics which include low standards of living, high corruption, oppressive regimes with low regard for human rights, poor provision for health care and education, as well as low levels of per capita income and foreign direct investment (Crane et al, 2008). On the other hand, solid legal procedures compel the enterprises to observe the regulations and guidelines for engagement in CSR activities. Although, this is not true to claim that corporations working in developing countries are never in compliance with the legal system of the land, but rather it is prioritizing after economic and philanthropic dimensions. From the discussion, it is hypothesized that:

H2c: There is no relationship between the legal dimension of CSR pyramid and FP.

Ethical Dimension: According to Carroll (1979 \& 1991), the ethical aspect of the CSR pyramid can be achieved by doing good while avoiding harm. According to Human Development Index (HDI) classification, Pakistan was placed in the medium human development category (3rd category) and ranked 147 (UNDP, Human Development report, 2016). Crane \& Matten (2004) observed that the ethical dimension of CSR is more significant in Europe while the comparison with the US. However, this may not be true in the case of developing countries, particularly in low ranking (HDI) countries, where the priorities are fulfilling only the basic needs with limited available budget and resources. The involvement in CSR activities is considered to be optional and not a mandatory in developing countries context. Therefore, the CSR activities are considered to be voluntary and depend on the decision (choice) of the enterprise (Wettstein, 2009). In more simple words, enterprises have the full discretion whether to involve in ethical corporate activities (CSR) or not. The parameters and standards of ethics are not universal in every society of the world. For example, the presence of child labor and working hours more than 12 hours a day are even not considered to be bad or illegal in many developing and poor countries. Hillman and Keim (2001) argued that taking part in resolving the social and ethical issues are negatively affect the firm's capability to earn a profit on the invested money of the shareholders. Scholars (e.g. Burns and Brady, 1996; Pettijohn \& Taylor, 2008) determined that ethical awareness is lower in developing countries as compared to other developed countries of the world while conducting a study in Malaysia. Other studies have examined that investing in ethical and social activities are wasting the shareholder's profit (Queen and Jones, 1999). On the basis of this rationale, the ethics are not more prioritized by the corporate world in the context of Pakistan too. Javed et al (2013) found a negative relationship between the FP and the ethics in the context of Pakistan by using Carroll model. From this discussion it is hypothesized that:

H2d: There is no relationship between the ethical layer of CSR pyramid and FP.

\section{Methodology}

This study has explored the answers of different hypotheses regarding the various dimensions with respect to FP in a specific local context. The CSR related data and information about the firm performance were collected from the annual reports of "Top 25 companies of the year" for 5 years (2011-2015). After scanning the list, a total of 51 companies were selected, with missing data for 3 companies. The sample covers twelve (12) industries classified under different sectors, for example chemical/fertilizers $(6.3 \%)$, automobiles $(8.3 \%)$, food \& personal care $(10.4 \%)$, exploration \& production $(8.3 \%)$, engineering $(8.3 \%)$, manufacturing $(14.6 \%)$, banking \& financials $(12.5 \%)$, consumer products $(4.2 \%)$, fuel/energy $(8.3 \%)$, logistics $(2.1 \%)$, insurance $(8.3 \%)$, and construction (8.3\%). To measure the level of CSRD, the author made more efforts to include maximum aspects and dimensions of CSR (e.g. KLD, GRI, ILO, ISO etc.) and quantify according to availability or unavailability. Earnings per share (EPS) were taken from the annual reports to calculate the FP for this study. The level of CSRD was measured with the help of content analysis (CA hereinafter). From the literature of overall management research, it is reflected that CA is the most accurate method to gather, investigate, analyze and measure the different social and financial dimensions from the text, graphs, figures, signs, idea or other published information of any corporation (Neuman, 2003). Berelson (1952) stated the process of CA in these words "this is a research technique for the objective, systematic and quantitative description of the manifest content of communication" (p. 18). 
The texts in the available reports are codified manually or mechanically against different dimensions of selected indicators (Weber, 1988). CA was used by a number of researchers in their social and environmental reporting for classifying the social reporting dimensions of disclosing corporations (e.g. Adams and Harte, 1999; Gray et al, 1995; Milne and Adler, 1999; Beck et al, 2010). In quantitative CA, the already assigned facts are extracted from the text and presented in percentage or numeric values depends on the frequency of occurrence of that text (Berelson, 1952; Krippendorff, 2004). Every document was scanned manually line by line and word by word to assure the authenticity and quality of desired extracted data. The text was scanned against the predefined parameters and was codified with " 1 " per sentence, as one sentence is equalized to "1". Milne and Adler (1999) demonstrate that "sentences are far more reliable than any other unit of analysis". If a sentence is having more than one dimension, then " 1 " was divided by the total number of dimensions in that sentence. For example, a corporation got a score of " 1 " if the relevant information is available in the annual report against the already designed CSR dimension or "0" in case of unavailability of information against that dimension. This type of technique was adopted by many researchers (e.g., Eng and Mak, 2003; Haniffa and Cooke, 2002).

A number of diagnostic tests were conducted for the regression analysis. There are four basic assumptions to be fulfilled for running a regression model; collinearity, heteroscedasticity, normality and linearity tests (Gujarati, 2012). The Hausman's test was also used to distinguish the variation of the panel data in the fixed effects model and the random effects model. Equation given below offers the relationship of CSRD relevant to different layers of CSR pyramid and FP in term of EPS based on the pooled OLS regression model.

$$
\mathrm{EPS}_{\mathrm{i}, \mathrm{t}}=\beta_{0}+\beta_{1} \mathrm{Eco}_{\mathrm{i}, \mathrm{t}}+\beta_{2} \text { Phil }_{\mathrm{i}, \mathrm{t}}+\beta_{3} \operatorname{Leg}_{\mathrm{i}, \mathrm{t}}+\beta_{4} \mathrm{Eth}_{\mathrm{i}, \mathrm{t}}+\mu
$$

Where, EPS $\mathrm{it}_{\mathrm{t}}$ stands for the earning per share and $\beta_{0}$ is the intercept of the equation. Eco is the portion of CSR content disclosed about the economic layer, Phil stands for the CSRD relevant to philanthropy, Leg stands for the CSRD related to obligation of the rules and regulation of the state, while Eth stands for the slice of CSRD relevant to moral and ethical behavior conducted by the firm in business operation.

\section{Analysis and Discussion}

\section{Descriptive Statistic}

Descriptive statistic was conducted to examine the overall picture of the experimental data, shown in below table. The median value for EPS is 16.71 , the mean is 33.63 , having SD of 52.53, with maximum and minimum values of 354.59 , and -32.84 , respectively. The economic layer has the average value of 53.66, mean value of 69.92, with a maximum and minimum of 256.19 and 0 respectively, having SD value 54.36. The philanthropic layer of the CSR pyramid has the median, mean, SD, maximum and minimum values of $20.46,38.71,47.66,312.00$ and 0 respectively. The legal layer has an average value of 40.34 , mean value of 64.23 , having SD of 73.22 , ranging from the maximum value of 436.81 to a minimum value of 0 . The last variable for the category of CSR pyramid in descriptive summary is the ethical layer, which possesses the maximum value of 36.50 to a minimum value of 0 . The mean value for the ethical disclosure is 7.94 , the median value of 5.50, with the SD value of 8.25 .

Table 1: Descriptive Statistics

\begin{tabular}{|l|lllll|}
\hline & Mean & Median & Std. Dev & Min & Max \\
\hline EPS & 33.63 & 16.71 & 52.53 & -32.84 & 354.59 \\
Economic & 69.92 & 53.66 & 54.36 & 0.00 & 256.19 \\
Philanthropic & 38.71 & 20.46 & 47.66 & 0.00 & 312.00 \\
Legal & 64.23 & 40.34 & 73.22 & 0.00 & 436.81 \\
Ethical & 7.94 & 5.50 & 8.25 & 0.00 & 36.50 \\
\hline Total Observation & 240 & 240 & 240 & 240 & 240 \\
\hline
\end{tabular}




\section{Carroll CSR Layers Trends (in \%)}

The following figure represents the importance of the CSR pillars for the sample period of five years (2011-2015). According to the details, the economic disclosure is more important for the CSR reporting in the context of the sample country with a total disclosure of 38.67 per cent. The second layer consists of the legal pillar with an individual percentage of (35.52 \%). Both of these layers confirm the sequence of the CSR's pyramid. The philanthropic layer is the third most important layer for reporting CSRD in Pakistan with an individual percentage of 21.42 , while the last layer, according to above details, is ethical dimension having individual percentile value of 4.39 .

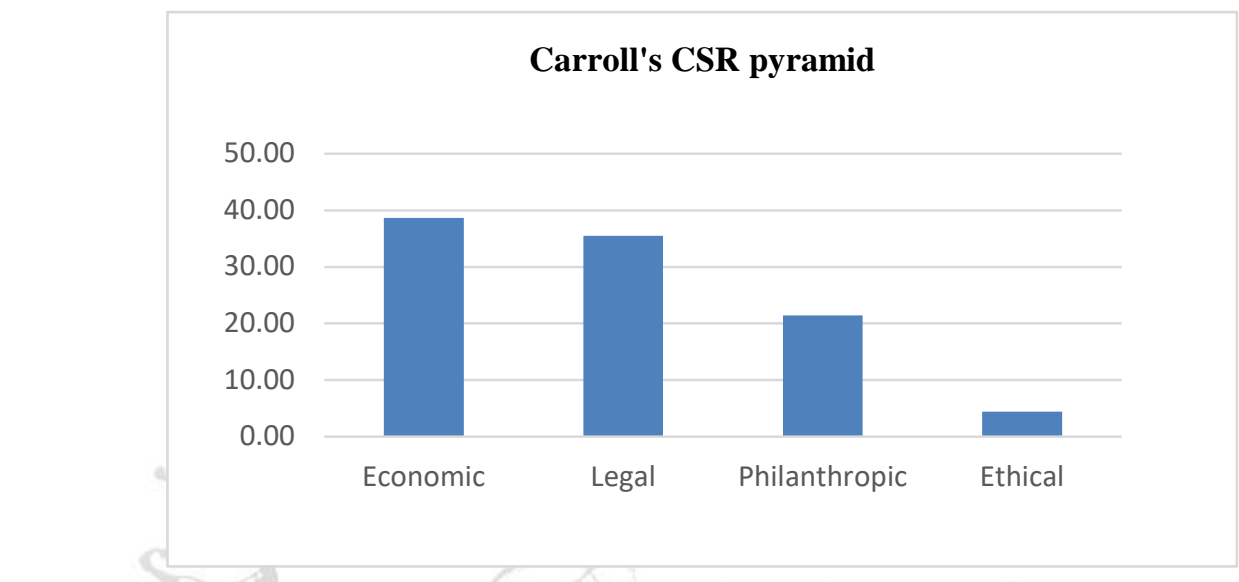

Figure 1: Carroll's CSR pyramid

\section{Yearly changes in CSRD of CSR pyramid' layers}

The figure given below shows the fluctuation in the layers of CSR pyramid for the year of 2012 and following years while comparing with the previous years. This fluctuation has been calculated by subtracting the current year from the previous year and divide by the previous year. The percentage was calculated by multiplying with 100. All the fluctuated (change) values have been converted to percentile values.

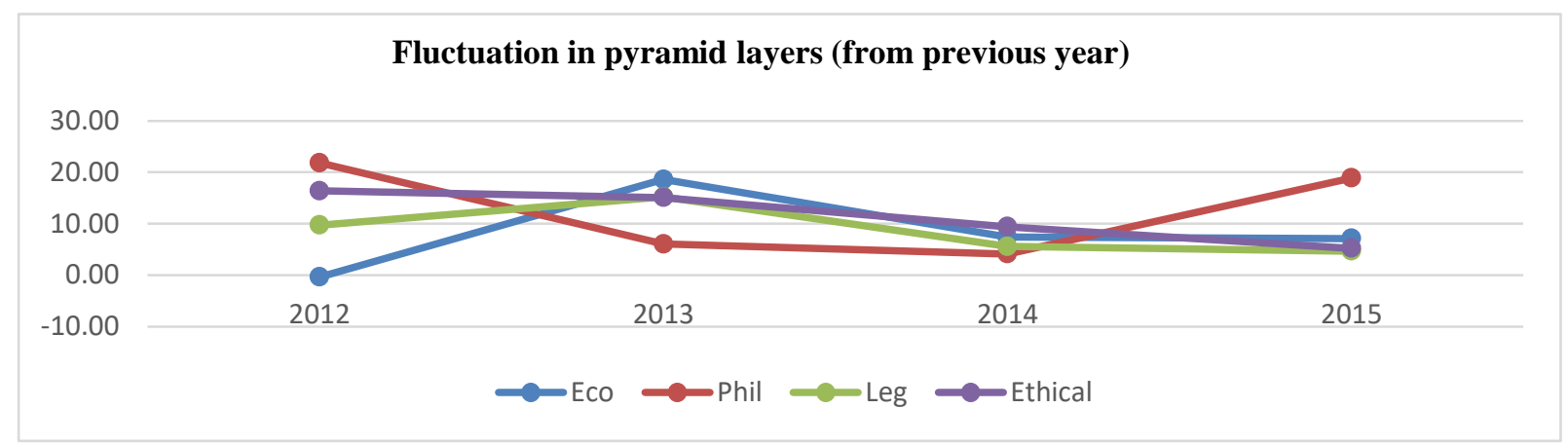

Figure 2: Fluctuation in pyramid layers (from previous year)

\section{Diagnostic Tests}

Correlation matrix and vector inflation factor (VIF) were used to test the issue of collinearity, shown in the following table. The values of the given variables are less than 0.70 (70 per cent) and 10 with the help of 
correlation matrix and VIF respectively, which shows that the matter of multicollinearity does not occur among the given variables. The results of Hausman specification test are portraying that the given models is highly significant and suggest that the pooled OLS model is adequate, in favors of the fixed effects alternative.

Table 2: Correlation Matrix

\begin{tabular}{|c|c|c|c|c|c|}
\hline \multicolumn{6}{|c|}{ Correlation Matrix } \\
\hline & EPS & Economic & Philanthropic & Legal & Ethical \\
\hline EPS & \multicolumn{5}{|l|}{1} \\
\hline Economic & $0.12 *$ & \multicolumn{4}{|l|}{1} \\
\hline Philanthropic & 0.31 *** & $0.44 * * *$ & \multicolumn{3}{|l|}{1} \\
\hline Legal & $0.16^{* * *}$ & $0.69 * * *$ & $0.64 * * *$ & \multicolumn{2}{|l|}{1} \\
\hline Ethical & -0.05 & $0.59 * * *$ & $0.25 * * *$ & $0.55 * * *$ & 1 \\
\hline \multicolumn{6}{|c|}{ Vector Inflation Factor (VIF) } \\
\hline \multirow{2}{*}{\multicolumn{2}{|c|}{$\begin{array}{l}\text { Variables } \\
\text { VIF Values }\end{array}$}} & \multirow{2}{*}{$\begin{array}{l}\text { Economic } \\
2.206\end{array}$} & Philanthropic & Legal & Ethical \\
\hline & & & 1.723 & 2.814 & 1.671 \\
\hline \multicolumn{6}{|c|}{ Hausman's test } \\
\hline $\mathrm{F}(1,234)$ & 21.6316 & \multirow{2}{*}{\multicolumn{4}{|c|}{$\begin{array}{l}\text { A low p-value counts against the null hypothesis that the pooled OLS model } \\
\text { is adequate, in favors of the fixed effects alternative. }\end{array}$}} \\
\hline P-value & 0.0000 & & & & \\
\hline
\end{tabular}

\section{Regression Analysis}

The product of the regression analysis for the above-mentioned model has shown in below table. It is very easy to notice from the OLS model that the economic and philanthropic related CSRD have a positive and significant relationship with the FP. This relationship shows the importance of base layer (economic) of the Carroll's CSR pyramid and the urgency of the charity and donation in developing countries, like Pakistan. On the other hand, legal and ethical related CSR are negatively related and insignificant to the FP with the help of OLS. These two layers were found to be irrelevant and are not affecting the firm performance in the context of Pakistan.

The results of the regression analysis conducted by fixed-effects model show that economic, philanthropic and legal related CSRD are statistically significant and positively related to FP. This relationship shows that the firm which discloses more CSRD relevant to economic, philanthropy and legal activities will be more financially profitable in term of EPS. The CSRD relevant to ethical layer of the CSR' pyramid was found to be significant but negatively related to the FP in term of earning per share (EPS). As proposed in the hypothesis, this layer of the CSR pyramid was found to be negatively related to the firm performance in term of EPS.

CSRD related to economic and philanthropic is directly related to the FP in term of EPS with the help of both regression analysis which certifies the argument that economic and philanthropy are the most important dimensions of CSR for FP operating in Pakistan. Unexpectedly, as proposed by the current study, the CSRD related to the legal dimension of CSR was also found to be positively related to FP on the basis of fixed-effects model. The last dimension of CSR is ethical, which was found to be negative related to the FP, supports the proposition of the study. 
Table 3: Regression Result

\begin{tabular}{|l|lll|llll|}
\hline & \multicolumn{3}{|l|}{ Pooled OLS } & & \multicolumn{3}{l|}{ Fixed-effects } \\
\hline Variables & Coefficient & t-ratio & $\begin{array}{l}\text { P- } \\
\text { Value }\end{array}$ & Coefficient & $\begin{array}{l}\text { t- } \\
\text { ratio }\end{array}$ & P-Value & \\
\hline Const & 23.03 & 1.67 & $*$ & 26.54 & 8.45 & $* * *$ \\
Economic & 0.09 & 2.64 & $* * *$ & 0.13 & 3.11 & $* * *$ & \\
Philanthropic & 0.36 & 5.53 & $* * *$ & 0.25 & 11.35 & $* * *$ & \\
Legal & -0.01 & -0.30 & & 0.01 & 3.20 & $* * *$ & \\
Ethical & -1.16 & -1.60 & & -1.60 & -2.31 & $* *$ & \\
\hline R-squared & 0.12 & $\begin{array}{l}\text { Adjusted } \\
\text { squared }\end{array}$ & 0.11 & R-squared & 0.19 & $\begin{array}{c}\text { Adjusted R- } \\
\text { squared }\end{array}$ & 0.177 \\
F (4, 235) & 8.02 & P-value(F) & 0.000 & F (5, 234) & 11.30 & $\begin{array}{c}\text { P- } \\
\text { value(F) }\end{array}$ & 0.000 \\
\hline
\end{tabular}

Crane and Matten (2007) noticed that all of the four dimensions of CSR's pyramid show different role when compared the developed and developing countries. Similarly, Visser (2011) retreated the dimensions of Carroll's pyramid in developing countries context and observed that the sequence of the CSR layers varying from the original order of the CSR's pyramid layers. The author further stated that economic layer is prioritized in developing countries, followed by the philanthropy, legal and then ethical dimensions. Despite the fact, that the practices and beliefs of the CSR are subjected to time and place, but the specific indicators and dynamics of the CSR are bound to the decision of an enterprise (Matten and Moon, 2008). Friedman (1970) was of the opinion that the only responsibility of an enterprise is to maximize the utilization of the corporate resources in business operation for the shareholder's profit within the boundaries of the law. The literature's developmental history also integrates various possibilities and development due to difference in standards of ethics, norms, values and even the economy. Similarly, the needs and priorities for living are also depending on the requirements of the local population. Porter and Kramer (2006) claimed that social variations permit the enterprise to modify the CSR activities. Hockerts and Morsing (2008) also put the objection regarding the classification of CSR pyramid in strict hierarchal order.

The satisfaction of economic layer is not only important for gaining the competitive edge over the peer groups but also guarantee a firm to be much stable and avoid the potential risk (Prahalad and Hammond, 2002). Campbell (2007) further claims the importance of satisfaction of this layer by emphasizing that basically due to this dimension an enterprise can participate in the socially responsible process. Typically, the economic layer of CSR dimension is assumed to be interchangeable with financial gain, which was misunderstood by the layman.

Basically, the economic dimension of the CSR pyramid submerges the wide range of responsibility, in dealing with the investments, manufacturing and providing the quality and economical goods and services. Freeman (1984) projected that the social activities should be integrated into the corporate economic activities, as these both have interdependency on each other. As a result, positive reputation and image of the enterprise are built among all the stakeholders, which leads to enhancing turnout due to product images (Smith \& Alcron, 1991), and thus increase the firm's profitability (Orlitzky et al, 2003). The acknowledgement of the available corporate resources has been taken from the viewpoint of resource-based theory in the research of many studies. Barney (1991) analysed that enterprises can achieve the competitive edge if they are having specific resources and proficiencies, which make their goods and services distinguish from their peer groups. Cefis (2003) found that the investment in innovation and research \& development enhances the firm profitability. The direct relationship between the corporate reputation and firm performance was also examined by numbers of other scholars (e.g. Peloza and Pepania, 2008; Eberl and Schwaiger, 2005; Roberts and Dowling, 2002). 
Liang and Renneboog (2017) examined a direct linkage between the charity and firm performance, by stating that charity/philanthropy is acting as gesturing device for potential FP. Kim (2012) conducted a study in the Korean context and found that those enterprises are enjoying much growth which is involved in corporate giving (charity). Philanthropy is considered to be the most sophisticated type of CSR activities in Africa (Visser, 2006). Unlike the compulsion in local law of Europe or other developed countries, the situation is different in Pakistan and other developing and emerging countries. There are many reasons behind this argument, for instance, poverty, unemployment, weak, incapable and corrupt institutions etc. Another argument might be that it is very important for the corporate activities to have a favourable condition with abundant resources and wealthy buyers. Therefore, the enterprises operating in such type of vulnerable societies are striving to uplift the living conditions of the local people to become productive employees and wealthy buyers. Such type of situation, where a win-win situation met between both groups is called the strategic philanthropy. Fombrun et al (2000) stated that in spite of the reason that the corporate giving (charity) is not directly related to the corporate financial performance in short-term, yet it can enhance the corporate reputation, legitimacy and employee loyalty and thus the financial performance in long-term. In Islamic society (Sharia Law), zakat is an obligatory payment on the surplus capital by an individual or corporation. These zakat funds are spent in different communal activities: orphanages, education, health and other projects. In this way, other stakeholder groups attain information about the corporate good cause, which enhances the firm reputation (McWilliams \& Siegel, 2001). The result of the current study is similar to the findings of the (Iqbal et al, 2014), who examined that the philanthropic activities enhancing the financial performance in the context of Pakistan. Similarly, the result also confirms the findings of other authors (e.g. Boatsman and Gupta, 1996; Waddock and Graves, 1997), who found a positive association between the corporate philanthropy and firm performance.

The fulfilment of the legal responsibility can build a strong association with the government institutions and political officials and thus avoid the legal penalties which might divert the core corporate activities of the enterprise. The relationship between the legal dimension of CSR and firm performance is mixed. Some of the research studies (e.g. Schnietz and Epstien, 2005) examined a direct linkage, while others (e.g., Wagner et al, 2002) observed an inverse relationship between the two indicators. Scholars (e.g. Qian et al, 2015; Mishra and Suar, 2010) have linked the concept of CSR legal dimension with the institutional theory. They claimed that the concept of CSR is still in a young stage in developing countries having weak institutional settings, standards and appeal processes. Campbell (2007) also linked the concept of CSR to institutional theory by stating that enterprises are involved in CSR activities due to many external forces. Other studies have also examined that the legal responsibility has a direct association with the corporate reputation (Pfau et al, 2008; Stanaland et al, 2011). Moreover, legal responsibility originates and enhances the corporate performance and thus leads to achieve corporate goals and sustainability (Longo et al, 2005). The stakeholders' theory emphasises the fulfilment of various stakeholders' needs, relevant to their status and urgency for corporation and stakeholders. Hond et al (2014) asserted that enterprises should show their devotions to the betterment of stakeholders, as well as political performance. Only in this way, the enterprise can operate in a more favourable corporate environment through regulations, governmental support, and also improved reputation.

From the literature of the past studies (e.g. Statman, 2006; Filbeck et al, 2009) it can be generalized that the fulfillment of the ethical layer of CSR dimension is generating sustainability and financial benefits. Borrowing the concept from institutional theory, Jennings \& Zandbergen (1995) declared the importance of fulfilment of all the social and ethical demands for gaining the sustainability within the given premises of the society. Hillman and Keim (2001) examined that whenever the ethical engagement is aligned with the social needs and accepted by the stakeholders, then it positively influences the corporate financial performance. This is due to the reason that ethical corporations are less exposed to stakeholder criticism and thus there is less chance to face a situation of lower sales turnover or products boycott by the buyers. Hatch (1993) structured a model which is called cultural dynamics. This model consists of the various code of conduct to reveal and indicate a firm's social image. According to Beheshtifar \& Korouki (2013), corporate reputation can be achieved by fulfilling the "set of collectively held beliefs about the firm's 
ability to satisfy the interests of stakeholders". Enterprise can build and maintain the corporate image by fulfilling the demands of stakeholders and aligning the corporate strategy with the local norms and value. Similarly, the CSR activities should include the fulfillment of all human basic rights and to act as a "good" and avoid "bad" in corporate activities for the building of the social harmony and attaining the corporate goals simultaneously. The enterprise working in developing countries are more focused towards the investors and customers only, as they considered that these are the fundamental groups of the stakeholders necessary for the existence of the business. It was proved empirically with the aspects of shareholders theory that involvement in ethical and social activities is basically diverting the resources of the shareholders (Hillman and Keim, 2001). Other studies have also examined that investing in ethical and social activities are wasting the shareholder's profit (Queen and Jones, 1999). Similarly, Hillman and Keim (2001) have also argued that taking part in resolving the social and ethical issues are negatively affecting the firm's capability to earn profit for shareholders. Pakistan is situated in Asia and belongs to a developing countries list. It was determined that ethical awareness is lower in developing countries as compared to other developed countries of the world while conducting a study in Malaysia (Burns and Brady, 1996; Pettijohn \& Taylor, 2008). On the basis of this rationale, the ethics are not more prioritized by the corporate world in the context of Pakistan too. The result of our study confirms the findings of other authors (e.g. Baucus and Near, 1991; Weaver et al, 1999) who also found a negative association between the ethics and FP.

\section{Conclusion}

Like other studies in the context of the developing countries, this study has also found that the order of the CSR pyramid is not universal. It was found that the economic and philanthropic dimensions are statistically significant and positive related with the FP in term of the EPS with the help of both regression models of the study. However, the legal and ethical dimensions were found to be statistically significant only with the help of a fixed-effects model. Hypothetically, the involvement in CSR activities is beneficial for a corporate image which then enhances the corporate performance. Although there was no negation with the importance of all the Carroll's CSR pyramid, however, the sequence and urgency were found to be different in developing countries than in developed countries. On the basis of analysis, it was found that there are more tendencies towards social work and community prosperity by executing different projects: for example, health assistance, promoting education, providing food and shelter to the vulnerable people and sponsoring different sports events.

The results of this study will support the researchers in identifying the different theoretical framework based on the CSR pyramid and the pattern and urgency of the corporate's social contribution in the context of Pakistan and other developing countries. The major advantage of this study is the exploration of different dynamics of the CSR concept which is parallel with the already proposed theories: for example, shareholder theory, stakeholder theory, institutional theory, legitimacy theory and Carroll CSR's pyramid.

\section{References}

Adams, C., \& Harte, G. Towards corporate accountability for equal opportunities performance[R]. ACCA occasional research paper no. 26. London: ACCA, 1999.

Barney, J. Firm resources and sustained competitive advantage. Journal of Management. 1991, 17(1): 99120.

Baucus, M. S., \& Near, J. P. Can illegal corporate behavior be predicted? An event history analysis. Academy of Management Journal, 1991, 34(1), 9-36.

Beck, C.A.; Campbell, D.; Shrives, P.J. Content analysis in environmental reporting research: Enrichment and rehearsal of the method in a British-German context. British Accounting Review, 2010, 42(2): $207-222$.

Beheshtifar, M., \& Korouki, A. Reputation: An important component of corporations' value. International Journal of Academic Research in Business \& Social Sciences, 2013, 3(7): 15-20. 
Berelson, B. L. Content analysis in communications research. New York: Free press, 1952.

Boatsman, J. R., \& Gupta, S. Taxes and corporate charity: Empirical evidence from micro level panel data. National Tax journal, 1996, 49 (2): 193-213.

Brammer, S. and Millington, A. The development of corporate charitable contributions in the UK: a stakeholder analysis. Journal of Management Studies, 2004, 41 (8): 1412-34.

Burns, D. J., \& Brady, J. T. Retail ethics as appraised by future business personnel in Malaysia and the United States. Journal of Consumer Affairs, 1996, 30(1): 195-217.

Burton, B., J.-L. Farh and W. Hegarty. A cross cultural comparison of CSR orientation: Hong Kong vs. US students. Teaching Business Ethics, 2000, 4(2): 151-167.

Campbell, J.L. Why would corporations behave in socially responsible ways? An institutional theory of CSR. Academy of Management Review, 2007, 32(2): 946-967.

Carroll, A. B. (1991). The pyramid of corporate social responsibility: Toward the moral management of organizational stakeholders. Business Horizons, 34(4), 39-48.

Carroll, A. B. A three-dimensional conceptual model of corporate performance. The Academy of Management Review, 1979, 4(4): 497-505.

Carroll, A. B. Corporate social responsibility: Will industry respond to cutbacks in social program funding?. Vital Speeches of the Day, 1983, 49: 604-608.

Cefis E. Persistence in innovation and profitability. Rivista Internazionale di Scienze Sociali, 2003, 111: 19-37.

Chapple, W. and Moon, J. Corporate social responsibility in Asia a seven-country study of CSR web site reporting. Business and Society, 2005, 44(4): 415-441.

Clarkson, M. A stakeholder framework for analyzing and evaluating corporate social performance. Academy of Management Review, 1995, 20(1): 92-117.

Crane, A. \& Matten, D. CSR as a field of scholarship. Corporate social responsibility, Volumes I, II \& III, Andrew Crane, Dirk Matten, London: Sage, 2007.

Crane, A. \& Matten, D. Managing corporate citizenship and sustainability in the age of globalization. Oxford: Oxford University Press, 2004.

Crane, A., Matten, D. and Spence, L. corporate social responsibility: Readings and cases in a global context. London: Routledge Taylor \& Francis Group, 2008.

Davis, K. The case for and against business assumption of social responsibilities. Academy of Management Journal, 1973, 16(2): 312-322.

Eberl, M. and Schwaiger, M. Corporate reputation: disentangling the effects on financial performance. European Journal of Marketing, 2005, 39(7/8): 838-854.

Elkington, J. Cannibals with Forks: Triple Bottom Line of 21st Century Business. Oxford: Capstone Publishing Limited, 1997.

Eng, L. L., \& Mak, Y. T. Corporate governance and voluntary disclosure. Journal of Accounting and Public Policy, 2003, 22: 325-345.

Filbeck G., Gorman R., Zhao X. The "Best Corporate Citizens": Are they good for their shareholders? Financial Review, 2009, 44(2): 239-262.

Fombrun, C. J., Gardberg, N. A., \& Barnett, M. L. Opportunity platforms and safety nets: corporate citizenship \& reputational risk. Business and Society Review, 2000, 105: 85-106.

Fox, T. Corporate social responsibility and development: In quest of an agenda. International Development, 2004, 47(3): 29-36.

Frederick, W.C. The growing concern over business responsibility. California Management Review, 1960, 2(4): 54-61.

Freeman, R.E. Strategic management: A stakeholder approach. Boston: Pitman, 1984.

Friedman, M. The social responsibility of business is to Increase its profits. The New York Times Magazine, 211-227, 1970.

Frynas, J. G. The false developmental promise of corporate social responsibility: Evidence from multinational oil companies. International Affairs, 2005, 81: 581-598.

Gabriel, P. P. MNCs in the third world: Is conflict unavoidable? Harvard Business Review, 1972, 50(4): 93-102. 
Gardberg, N.A.; Fombrun, C.J. Corporate citizenship: Creating intangible assets across institutional environments. Acad. Manag. Rev. 2006, 31: 329-346.

George, G., Howard-Grenville, J., Joshi, A. and Tihanyi, L. Understanding and tackling societal grand challenges through management research. Academy of Management Journal, 2016, 59(6): 1880-1895.

Gray, S. Meek, G. and Roberts, B. International capital market pressures and voluntary annual report disclosures by US and UK multinationals. Journal of International Financial Management and Accounting, 1995, 6 (1): 43-68.

Gujarati, Damodar N. Basic econometrics. New York: McGraw-Hill Education, 2012.

Haniffa, R.M. and Cooke, T.E. Culture, corporate governance and disclosure in Malaysian corporations. Abacus, 2002, 38(3): 317-349.

Hatch, M. J. The dynamics of organizational culture. The Academy of Management Review, 1993, 18(4), 657-693.

Hillman, AJ \& Keim, GD. Shareholder value, stakeholder management, and social issues: What's the bottom line? Strategic Management Journal, 2001, 22(2): 125-139.

Hockerts, K., \& Morsing, M. A literature review on CSR in the innovation process. Copenhagen Business School (CBS), Center for corporate social responsibility, 2008: 1 -28.

Hond, F., Rehbein, K. A., Bakker, F. G. A., \& Lankveld, H. K. Playing on two chessboards: Reputation effects between CSR and corporate political activity (CPA). Journal of Management Studies, 2014, 51(5): 790-813.

Husted, B. Governance choices for corporate social responsibility: to contribute, collaborate or internalize? Long Range Planning, 2003, 36(5): 481-498.

Iqbal, N., Ahmad, N., Hamad, N., Bashir, S., \& Sattar, W. Corporate social responsibility and its possible impact on firm's financial performance in banking sector of Pakistan. Arabian Journal of Business and Management Review (Oman Chapter), 2014, 3(12): 150-155.

Jamali, \& Miurshak. Corporate social responsibility (CSR): Theory and practice in a developing country context. Journal of Business Ethics, 2007, 72(3): 243-262.

Jamali, D., Sidani, Y. and El-Asmar, K. A three-country comparative analysis of managerial CSR perspectives: insights from Lebanon, Syria and Jordan. Journal of Business Ethics, 2009, 85(2): 173192.

Javed Muzhar, Saeed Rashid, Lodhi Rab Nawaz, Malik Qamar Uz Zaman. The relationship between corporate social responsibility and firm's financial performance: A case of Pakistan. Journal of Basic and Applied Scientific Research. 2013, 3(11): 34-45.

Jennings, P. D., \& Zandbergen, P. A. Ecologically sustainable organizations: An institutional approach. The Academy of Management Review, 1995, 20(4): 1015-1052.

Khan, M., A. Majid, M. Yasir, M. Arshad. Corporate social responsibility and corporate reputation: A case of cement industry in Pakistan. Interdisciplinary Journal of Contemporary Research in Business, 2013, 5(1): 843-957.

Kim, H. G. The Impact of cumulative effect of cash donation on business performance. Journal of the Korea society of computer and information, 2012, 17(4): 147-153.

Krippendorff, K. Content analysis: An introduction to its methodology. Thousand Oaks, California: Sage Publications Inc, 2004.

Liang, H., and Renneboog, L. On the foundations of corporate social responsibility. Journal of Finance, 2017, 72: 853-910.

Lindgreen, A. \& Swaen, V. Corporate social responsibility. International Journal of Management Reviews, 2010: 1-7.

Longo, M., Mura, M. and Bonoli, A. Corporate social responsibility and corporate performance: The Case of Italian SMEs. Corporate Governance, 2005, 5(4): 28-42.

Maignan, I. Consumers' perception of corporate social responsibility: A cross cultural perception. Journal of Business Ethics, 2001, 30(1): 57-72.

Matten, D. and Moon, J. "Implicit" and "Explicit" CSR: A conceptual framework for a comparative understanding of CSR. Academy of Management Review, 2008, 33: 404-424.

Matten, D., Moon, J. and Crane, A. Can corporations be citizens? Corporate citizenship as a metaphor for 
business participation in society. Business Ethics Quarterly, 2005, 15: 429-53.

McWilliams, A. and Siegel, D. Corporate social responsibility: a theory of the firm Perspective. Academy of Management Review, 2001, 26 (1): 117-127.

Meadows, D.H., Randers, J. and Meadows, D.L. Limits to Growth: The 30- Year Update. Chelsea Green Publishing Co, White River Junction, VT, 2004.

Mescon, T.S., \& Tilson, D.J. Corporate philanthropy: A strategic approach to the bottom-line. California Management Review, 1987, 29(2): 49-61.

Milne, M J and Adler, R W. Exploring the reliability of social and environmental disclosures content analysis. Accounting, Auditing \& Accountability Journal, 1999, 12(2): 237-256.

Mishra, S.; Suar, D. Does corporate social responsibility influence firm performance of Indian companies? . J. Bus. Ethics, 2010, 95: 571-601.

Moon, J. and Vogel, D. Corporate responsibility, government and civil society. in Crane, A., McWilliams, A., Matten, D., Moon, J. and Siegel, D. (Eds), The Handbook of corporate social responsibility, Oxford University Press, Oxford, pp. 303-326, 2008.

Neuman, W. Social research methods: Qualitative and quantitative approaches. Boston, MA: Allyn \& Bacon, 2003.

Nidumolu, R., Prahalad, C.K. and Rangaswami, M.R. (2009), Harvard Business Review, September.

Orlitzky, M., Rynes, F. L., \& Schmidt, S. L. Corporate social and financial performance: A meta-analysis. Organization Studies, 2003. 24: 103-441.

Peloza, J., \& Papania, L. The missing link between CSR and financial performance: stakeholder salience and identification. Corporate Reputation Review, 2008, 11: 169e181.

Pettijohn, C., Pettijohn, L., \& Taylor, A. J. Salesperson perceptions of ethical behaviors: Their influence on job satisfaction and turnover intentions. Journal of Business Ethics, 2008, 78(4): 547-557.

Pfau, M.; Haigh M.; Sims, J. and Wigley, S. The influence of corporate social responsibility campaigns on public opinion[J]. Corporate Reputation Review, 2008, 11(2): 145-154.

Podnar, K. \& Golob, U. CSR expectations: The focus of corporate marketing. Corporate Communications: An International Journal, 2007, 12(4): 326-340.

Porter, M. and Kramer, M. Strategy and society: The link between competitive advantage and corporate social responsibility. Harvard Business Review, 2006, 84 (12): 78-93.

Porter, M. and Kramer, M. The competitive advantage of corporate philanthropy. Harvard business review on CSR. Boston: Harvard Business School Press, 27-64, 2003.

Prahalad, C.K. and Hammond, A. Serving the world's poor, profitability. Harvard Business Review, 2002, 80(9): 48-59.

Qian, W.; Junsheng, D.; Shenghua, S. A meta-analytic review of CSR and corporate financial performance: The moderating effect of contextual factors. Bus. Soc. 2015, 55: 1-39.

Roberts, P. and Dowling, G. Corporate reputation and sustained superior financial performance. Strategic Management Journal. 2002, 23(12): 1077-1093.

Schnietz, K.E.; and Epstein, M.J. Exploring the financial value of a reputation for corporate social responsibility during a crisis. Corporate Reputation Review, 2005, 7 (4): 327-345.

Sheikh, S. \& Beise-Zee, R. Corporate social responsibility or cause-related marketing? The role of cause specificity of CSR. Journal of Consumer Marketing, 2011, 28(1): 27 - 39.

Smith, S. M., \& Alcron, D. S. Cause marketing: A new direction in the marketing of corporate responsibility. Journal of Consumer Marketing, 1991, 8(3), 19e35.

Stanaland, A.; Lwin, M. and Murphy, P. Consumer perceptions of the antecedents and consequences of CSR. Journal of Business Ethics, 2011, 102 (1): 47-55.

Statman M. Socially Responsible Indexes: Composition, performance and tracking error. Journal of Portfolio Management, 2006, 32(3): 100-109.

Ullmann, A. Data in search of a theory: A critical examination of the relationships among social performance, social disclosure, and economic performance of the US firms. Academy of Management Review, 1985, 10(3): 540-57.

UNDP. "Human Development Report 2016 - "Human Development for Everyone"" (PDF). HDRO (Human Development Report Office) United Nations Development Program. pp. 198-201. Retrieved 
on 7th August 2017.

Unerman, J. and Chapman, C. Academic contributions to enhancing accounting for sustainable development. Accounting, Organizations and Society, 2014, 39: 385-394.

Visser, W. (2006) Revisiting Carroll's CSR pyramid, An African perspective, chapter 1 in corporate citizenship in developing countries, Mahad Huniche, Frederiksberg: Copenhagen Business School.

Visser, W. The age of responsibility: CSR 2.0 and the new DNA of business. West Sussex: John Wiley \& Sons, 2011.

Waddock, S.A., Graves, S.B. The corporate social performance financial performance link. Strateg. Manage. J., 1997, 18 (4): 303-319.

Wagner, M., Van, P. N., Azomahou, T., Wehrmeyer, W. The relationship between the environmental and economic performance of firms: An empirical analysis of the European paper industry. CSR and Environmental Management, 2002, 9(3), 133-146.

Walton, C. Corporate Social Responsibilities. Belmont: Wadsworth, 1967.

Weaver, G. R., Trevino, L. K., \& Cochran, P. L. Integrated and decoupled corporate social performance: Management commitments, external pressures, and corporate ethics practices. Academy of Management Journal, 1999, 42(5): 539-552.

Weber, R.P. (1988): Basic content analysis, Sage University Paper series on quantitative applications in the social sciences, Series No. 07-049. CA: Sage, Beverly Hills, 1988.

Wettstein, F. Beyond voluntariness, beyond CSR: making a case for human rights and justice. Business and Society Review, 2009, 114(1): 125-52.

Windsor, D. Corporate citizenship: evolution and interpretation. in perspectives on corporate citizenship edited by J. Andriof and M. McIntosh. Sheffield: Greenleaf Publishing, 2001.
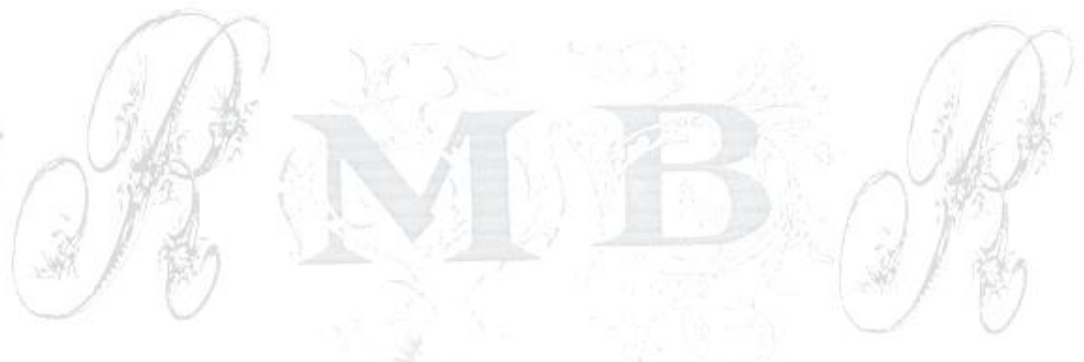